\title{
Colorado Seed Potato Certification Data Analysis Shows Mosaic and Blackleg are Major Diseases of Seed Potato and Identifies Tolerant Potato Varieties
}

\author{
Yuan Zeng and Ana Cristina Fulladolsa, Department of Bioagricultural Sciences and Pest Management, Colorado State University; Andrew \\ Houser, Department of Horticulture and Landscape Architecture, Colorado State University; and Amy O. Charkowski, ${ }^{\dagger}$ Department of Bio- \\ agricultural Sciences and Pest Management, Colorado State University
}

\begin{abstract}
Seed potato certification programs aim to limit disease incidence in planting material to levels below a threshold that causes significant losses to seed potato buyers. Records maintained for seed potato certification can be analyzed for trends in seed potato varietal mixture and disease incidences over time. We used logistic regression models to determine effects of year, potato variety, and their interaction on the incidences of potato diseases and disorders based on seed potato certification data collected in Colorado from 2012 to 2016. The effect of seed generation of important varieties on the incidence of common potato diseases was also quantified. Among the documented diseases, mosaic, caused primarily by Potato virus $Y$, is a persistent problem leading to high percentage of seed lot rejections in both summer and winter inspections, while blackleg, caused by Dickeya spp. and Pectobacterium spp., was a common disease causing summer rejections. The model demonstrated year, potato variety, and their interaction were key factors contributing to incidence of varietal mixture, or one or more potato diseases and disorders. For

summer inspections, our models identified 53, 42, and six varieties sensitive to mosaic, blackleg, and leafroll, respectively. There were 17, 15, and six varieties that were tolerant to mosaic, blackleg, and leafroll regardless of pathogen pressures in the environment. For winter inspections, 51 varieties were sensitive to mosaic and three to leafroll, whereas 45 and one were relatively tolerant to mosaic and leafroll. The pattern of seed generation effects of selected potato varieties on mosaic and blackleg incidence was inconsistent across inspection years. In addition, we observed a significant negative correlation between the relative abundance of the green peach aphid, Myzus persicae, and mosaic in winter inspections. Mosaic incidences in summer and leafroll incidences were not influenced by common aphid species captured or total aphids in the valley. These results identify mosaic and blackleg as major causes of seed potato rejections and downgrades, sensitive and tolerant varieties, and provide suggestions for improving integrated crop management practices in Colorado.
\end{abstract}

Seed potato health cannot be accurately assessed by visually inspecting tubers. Seed certification programs benefit crop production by providing a third-party evaluation that spans both the current growing season and connects seed potato generations across years. Current certified seed potato production begins by planting diseasefree tissue culture plants in pots or in a hydroponic system in a greenhouse to produce nuclear seed. The nuclear seed is then planted in the field to produce the first seed generation (generation 1), which then produces generation 2 and so forth (Bohl et al. 1992). The risk of disease is thought to increase with each field generation (Rahman et al. 2010), so seed potato growers use a limited generation system and typically do not plant seed older than generation 6.

Each generation is inspected during the summer growing season and a postharvest inspection is done in the winter to assign a

${ }^{\dagger}$ Corresponding author: A. O. Charkowski;

E-mail: Amy.Charkowski@colostate.edu

Funding: This work is supported by the USDA National Institute of Food and Agriculture (grant SCRI 73999-10921) and USDA-Animal and Plant Health Inspection Service award 59-8062-001.

Any opinions, findings, conclusions, or recommendations expressed in this publication are those of the author(s) and do not necessarily reflect the view of the U.S. Department of Agriculture.

*The $\boldsymbol{e}$-Xtra logo stands for "electronic extra" and indicates that seven supplementary tables are published online.

Accepted for publication 18 August 2018.

() 2019 The American Phytopathological Society certification class to each seed lot (Frost et al. 2013). Although certification systems differ in details, all programs rely on a limited generation system with the first planting initiated from aseptic cultured plants or tubers, in some states designated as the nuclear generation. Subsequent generations are limited to four to six generations depending on state and some states designate classes by number of years planted in soil (field year). If tolerances are not met for specific generations, they may be downgraded. Each state has its own tolerances for recertification and will only allow seed lots to be imported from another state if it meets their tolerances. The long-term impact of seed potato certification is a reduction of significant seed potato borne diseases, improvements in varietal purity, and increases in yield. Seed certification programs also provide substantial and long-term data records in crops that aid in determining patterns of variability and their relationships with changes in crop management practices or the environment (Magnuson 1990; Sagarin and Pauchard 2010), but these records are rarely analyzed. Among seed certification programs of vegetatively propagated crops in the U.S., the most extensive and long-lived certification efforts are the century-long programs in potato (Shepard and Claflin 1975; Whitworth and Davidson 2008).

Of the pathogens that seed potato farmers currently encounter, the most important pathogen and the most common reason for rejection of seed potatoes is the potyvirus Potato virus $Y$ (PVY). This virus can be transmitted in seconds by numerous aphid species in a nonpersistent manner, so insecticides are not effective in preventing PVY spread. PVY is responsible for foliar mosaic and occasionally tuber necrosis (Gray et al. 2010). A second important virus is Potato leafroll virus (PLRV), a polerovirus which is transmitted by a few species of aphids (Taliansky et al. 2003), though its occurrence seems to be reduced by widespread use of systemic neonicotinoid insecticides in recent years (Frost et al. 2013; Loebenstein and Gaba 2012). Other viruses, including Potato virus $S$ (PVS) and Potato virus $X$ (PVX), 
which are mechanically transmitted, and a seedborne and mechanically transmitted viroid, Potato spindle tuber viroid (PSTVd), are also problematic pathogens that can limit potato production and trade (Loebenstein and Gaba 2012; Scholthof et al. 2011). PTSVd and PVX are managed by pathogen-free planting stocks, sanitation, and a limited generation system. Importantly, PSTVd has not been reported in North American seed potatoes for several decades (Singh 2014; Sun et al. 2004); however, it is still sporadically found in greenhouse-grown tomatoes in North America (Ling and Sfetcu 2010; Ling et al. 2013). In North America, PVS is both widespread and essentially ignored in potato production due to its minimal impact on yield and quality.

Recently, growers have perceived an increase in blackleg incidence caused by the bacterial pathogen Dickeya dianthicola throughout North America. A related group of pathogens, Pectobacterium spp. such as $P$. brasiliensis and $P$. atrosepticum also causes blackleg, aerial stem rot, and bacterial soft rot of potato and is found in all potato growing regions (Ali et al. 2012; De Boer 2004). Methods used to assess and report blackleg in seed potatoes vary across North America. Colorado is one of only a few states that has long-term records on blackleg incidence and an extensive historical strain collection from infected plants and environmental sources.

In the past, long-term seed potato datasets have been used to compare trends in pathogen prevalence with environmental conditions and aphid population sizes (Bagnall 1988, 1992). A recent study examined year and aphid abundance effects on the proportion of clean lots without mosaic symptoms and the varietal responses to PVY, based on over 20 years of data collected in the Wisconsin Seed Potato Certification Program (WSPCP). The study aimed to correlate disease trends with changes in pathogen epidemiology or crop management practices (Frost et al. 2013). In our study, we used a statistical approach to investigate factors that contribute to incidences of varietal mixture, diseases, and disorders in the seed potato certification program in Colorado. Accordingly, the objectives of the present study were i) to analyze variability of potato diseases and disorders and indications of errors in cultivation (i.e., varietal mixture) as a function of year, potato variety, and the interaction of year and variety; ii) to examine the effect of seed generation of important varieties on the incidence of common potato diseases; and iii) to determine relationships between the relative abundance of aphids and disease incidences of mosaic and leafroll across the inspection years.

\section{Materials and Methods}

Seed potato certification data. Seed potato certification data collected in both summer and winter inspections from 2012 to 2016 were obtained from the SLV Research Center of Colorado State University, the designated authority for seed potato certification in Colorado. For each year, the number of lots and plants that were visually inspected, and the number of plants with diseases, disorders, and varietal mixture were recorded. Inspection tolerances for summer and winter inspections are provided in Supplementary Table S7. For the winter inspections, seed tubers (a typical sample size is 400 tubers per seed lot; for seed lots $<1$ acre, a smaller sample is required) were kept warm and treated with Rindite to break dormancy before they were planted in Oahu, Hawaii, around the first week of November. The plants were visually inspected in December or January with some ELISA testing based on growers' requests. Other information, such as farm, seed source, potato variety, and seed generation, was also included in the certification data. The number of rejected lots were counted based on incidence of potato disease or disorder symptoms exceeding tolerance levels by generation according to Colorado rules and regulations for certification of seed potatoes (http://www. coloradocertifiedpotatogrowers.com/downloads/PCS-rules-2013.pdf). Throughout this manuscript, we chose to use the term tolerance rather than resistance because the data are based on visual inspection of disease symptoms rather than detection of the presence/absence of the pathogen.

Aphid data. Weekly aphid monitoring data of the SLV region including green peach aphid (Myzus persicae), potato or pea aphid (Macrosiphum euphorbiae or Acyrthosiphon pisum), Russian wheat aphid (Diuraphis noxia), and miscellaneous aphids were obtained from Agro Engineering (http://www.agro.com/aphidnumbers.html). The number of aphids collected from IPM pan traps (34 traps in total) in the inspection years were averaged for each year, location, and week combination.

Statistical analysis. Logistic regression was applied to our dataset to examine treatment effects (year, potato variety, and the interaction of year and variety) on the incidences of potato diseases, disorders, or varietal mixture across all inspection years. For our dataset, we considered the log odds of each disease/disorder incidence as a linear function of the predictor variables with a binomial distribution. The logistic regression model for predictors $X_{1} \ldots X_{3}$ was expressed as:

$$
\log \left(\frac{P}{1-P}\right)=\beta_{0}+\beta_{1} X_{1}+\beta_{2} X_{2}+\beta_{3} X_{3}+\varepsilon_{1},
$$

where $P$ denoted the disease/disorder incidence (the number of plants with clear symptoms divided by total number of plants inspected), $X_{1} \ldots X_{3}$ stood for year, variety, and their interaction, respectively, and $\varepsilon_{1}$ was the measurement error. The year 2016, Yukon Gold, and their interaction were used as baselines for multiple comparisons.

Furthermore, the difference in disease incidences of seed generations of selected potato varieties based on their agricultural importance and identified likelihood of showing symptoms of mosaic or blackleg was examined in separate models as:

$$
\log \left(\frac{P}{1-P}\right)=\beta_{0}+\beta_{1} X_{1}+\beta_{2} X_{2}+\beta_{3} X_{3}+\varepsilon_{2},
$$

where $P$ denoted the disease incidence of mosaic or blackleg, $Y_{1} \ldots Y_{3}$ stood for variety, generation, and their interaction, respectively, and $\varepsilon_{2}$ was the measurement error. The latest generation, Teton Russet, and their interaction were used as baseline for the analysis.

In the above two models, a subject-effect was specified by the interaction of farm and seed source, and thus responses within the same subject were assumed to be correlated. Potato varieties with predicted possibility of showing a symptom $>0.5$ were classified as sensitive varieties, while varieties with $<0.5$ possibility were classified as tolerant varieties. All logistic regression analyses were carried out using PROC GENMOD at a significant level of $\alpha=0.05$.

Additionally, numbers of aphids captured were averaged for each year across sampling date and locations, and subjected to log-transformation. The average of disease incidence of mosaic and leafroll was also calculated for each year, and then transformed by square-root. Pearson correlations were calculated among disease incidence and vector abundance in the resulting data using PROC CORR.

All statistical analyses were performed using the statistical software SAS University Edition (https://www.sas.com/en_us/software/ university-edition.html).

\section{Results}

Disease prevalence and cause of rejected seed potato lots. The records of seed potato certification data of SLV provide substantial information on variability of potato disease and disorders including mosaic, blackleg, leafroll, calico, spindle tuber, bacterial ring rot, variant, haywire, and giant hill, as well as varietal mixture. Of the potato diseases that local farmers encountered, mosaic disease, which is commonly caused by PVY, was a persistent problem in both summer and winter inspections, with a range of incidence of $0-100 \%$ in summers and $0-73.5 \%$ in winters. The PVY incidences in the winter inspection were always higher than those in the summer inspection within the same year (Table 1). Blackleg, caused by the bacterial pathogens Pectobacterium spp. and Dickeya spp., was also common, leading to high incidences in the summer inspections. However, the incidences of variant (somatic mutation), calico (Alfalfa mosaic vi$r u s$ ), haywire (phytoplasma), and giant hill (somatic mutation) were relatively low. We did not identify any symptoms of spindle tuber (PSTVd) or bacterial ring rot (Clavibacter michiganensis subsp. sepedonicus) during these years (Table 1).

The certification data also provide information on rejected seed potato lots (i.e., disease or disorder incidence of a seed lot on the second 
inspection that exceeds the allowed percentages by seed generation). Notably, a higher proportion of seed lot rejections was identified in $2013(15.73 \%)$ in the summer inspections. The rejections based on winter inspections were higher in 2012 (11.71\%) and 2014 (11.15\%) when compared with other years (Fig. 1A). Interestingly, lot rejections measured in the winter inspections was a good predictor of lot rejections observed in the subsequent summer inspection; a one-unit increase of lot rejection ratio in the winter inspections resulted in an approximately 1.05-unit increase of lot rejection ratio in the subsequent summer inspections (Fig. 1B). The percentage of plants with mosaic disease varied in both summer and winter across inspection years, but it is the most common potato disease. Mosaic caused approximately $69 \%$ of seed potato lot rejections in summer and $100 \%$ of seed lot rejections in winter, except in 2012 (Fig. 2). Potato blackleg is also prevalent in the SLV and it consistently caused about $17 \%$ of rejected lots in the summer inspections (Fig. 2). Although potato leafroll, caused by PLRV, has been greatly reduced through the application of neonicotinoid insecticides, it is still a major problem in organic farms. In 2013, PLRV caused approximately $4.6 \%$ of summer rejections of organic seed potato lots. In addition, about $4.1 \%$ of summer rejections were caused by a combination of diseases; if total disease incidence from multiple causes exceeds an allowed tolerance level, seed lots are rejected (Fig. 2). Over this same time period, 5.5\% of seed lots in the summer inspections were rejected due to human errors that led to identification of varietal mixture, and it appeared to be a significant problem in summer 2016 (Table 1; Fig. 2).

The effect of year, potato variety, and their interactions on disease variability. Based on the logistic regression models we constructed, there were significant differences for incidences of mosaic, blackleg, leafroll, and varietal mixture in summer among inspection years $\left(P_{\text {year, mosaic, summer }}<0.0001 ; P_{\text {year, blackleg, summer }}<0.0001\right.$; $P_{\text {year, leafroll, summer }}<0.0001 ; P_{\text {year, varietal mixture, summer }}=0.0007$, respectively), while mosaic was the only disease that showed a difference in the winter inspections $\left(P_{\text {year, mosaic, winter }}<0.0001\right)$. There was no significant variation across years for the other inspection categories (Table 2). Notably, 2013 was a particular high year for summer rejections due to mosaic (PVY), which was supported by the common odds ratio of mosaic incidence of about 3.048 for an individual seed lot. This result indicated the probability of an individual seed lot showing mosaic symptoms in the San Luis Valley in 2013 was larger than $0.75\left(\beta_{2013}\right.$, summer $\left.=1.1146, P<0.0001\right)$. In contrast, the predicted odds ratio of a seed lot with mosaic disease in the winter inspections was 0.61 in 2013 and 0.45 in $2015\left(\beta_{2013}\right.$, winter $=$ $-0.4987, P=0.0001 ; \beta_{2015}$, winter $\left.=-0.8057, P<0.0001\right)$; thus, the probabilities of each seed lot having some mosaic disease in the postharvest test of 2013 and 2015 were 0.38 and 0.31 . More varietal mixtures occurred in 2012, where probability of varietal impurity in a seed lot was predicted to be 0.24 when compared with the baseline of 2016 (Table 1; Supplementary Table S4; $\beta_{2012, \text { summer }}=$ $-1.1489, P=0.0434 ; \beta_{2016}$, summer $=0$ ).

Certain potato varieties appeared to be consistently more sensitive or tolerant to infections of mosaic, blackleg, and leafroll, as well as to the development of variants during the summer or winter inspections (Table 2; Supplementary Tables S1, S2, and S3). When compared with the baseline variety Yukon Gold, our analysis on summer inspection data indicated that 53, 42, and six varieties showed symptoms of mosaic, blackleg, and leafroll more often, respectively, whereas 17, 15, and six varieties were less sensitive to mosaic, blackleg, and leafroll diseases regardless of pathogen pressures in the environment across inspection years. For the winter inspections, 51 and three varieties were more sensitive to mosaic and leafroll, respectively, and 45 and one were relatively tolerant to mosaic and leafroll. None of the varieties that were tolerant to mosaic were also tolerant to blackleg or leafroll.

As an example, of the varieties most sensitive to mosaic in the summer inspections, Russet Norkotah 112, contributed the most to the disease incidence. Our model suggested that the probability of a Russet Norkotah 112 seed lot developing mosaic is 0.9988 ( $\left.\beta_{\text {Russet Norkotah 112 }}=6.6958, P<0.0001\right)$. However, the probability of being infected by mosaic was estimated to be 0.0084 when Agata was planted $\left(\beta_{\text {Agata }}=-4.7771, P=0.0458\right)$, due to its relative tolerance. Similar patterns with other potato variety responses to blackleg and leafroll can be found in the supplementary materials. We found that 10 potato varieties (Blazer Russet, Colorado Rose, Crimson King, Dark Red Chieftain, DT6063-1R, Rio Grande Russet, Russet Norkotah 3, Russet Norkotah 112, Russet Norkotah 278, and Tebina) were predicted to have similar sensitivity to both mosaic and blackleg based on summer inspections, while 10 other varieties (Agata, Alegria, Ciklamen, Gala, Lamoka, LaRatte, Laura, Modoc, NY 115, Satina, and Teton Russet) were predicted to be tolerant to PVY but have higher sensitivity to blackleg.

The interaction of year and potato variety played a significant role in incidences of mosaic, blackleg, leafroll, or varietal mixture in both summer and winter inspections (Table 2), indicating that some potato varieties that were not predicted to be as highly sensitive or tolerant across all recorded years still occasionally contributed more or less to disease incidences. A high proportion of the significant yearvariety interactions with mosaic disease occurred with varieties known to show mild mosaic symptoms when infected with PVY, such as Russet Norkotah, Crestone Russet, Mesa Russet, Chieftain, Chipeta, CalWhite, and several fingerling varieties (http://seedcert.oregonstate. edu/sites/default/files/potato/PIE/variety-L_files/paa-latentvarieties.pdf). This suggests that much of the year-by-variety interaction that occurred with mosaic disease may be due to mild mosaic symptom development that is either missed by inspectors or affected by crop year.

The effect of seed generations on disease incidences of mosaic and blackleg. Seed potato farmers use a limited generation production system because risk of high disease incidence is thought to increase with each additional year a seed crop is increased in the field (Rahman et al. 2010). We selected 16 varieties based on their agricultural importance to determine if disease incidences of mosaic or blackleg varied among seed generations. The logistic regression model incorporated variety, generation, and the interaction of variety and generation as factors leading to disease incidences. The results indicated that all of them are key factors that influence the occurrence of mosaic and blackleg through inspection years (Table 3; Ps <

Table 1. Number of plants and lots inspected in summer and winter inspections (2012-2016) and the annual prevalence of common potato diseases, disorders, and varietal mixture that occurred in local farms of the SLVa

\begin{tabular}{|c|c|c|c|c|c|c|c|c|c|c|c|}
\hline & \multirow[b]{2}{*}{ Year } & \multirow[b]{2}{*}{ Plants Inspected } & \multirow[b]{2}{*}{ Lots Inspected } & \multicolumn{5}{|c|}{ Diseases } & \multirow[b]{2}{*}{ Varietal Mixture } & \multicolumn{2}{|c|}{ Disorders } \\
\hline & & & & Mosaic & Blackleg & Leafroll & Calico & Haywire & & Variant & Giant Hill \\
\hline \multirow[t]{5}{*}{ Summer } & 2012 & $2,116,106$ & 1,067 & 14,910 & 5,320 & 58 & 39 & 8 & 172 & 56 & 1 \\
\hline & 2013 & $1,724,457$ & 966 & 25,784 & 4,620 & 1,782 & 46 & 8 & 166 & 59 & 0 \\
\hline & 2014 & $1,574,550$ & 942 & 6,794 & 4,791 & 107 & 25 & 3 & 141 & 82 & 0 \\
\hline & 2015 & $1,466,450$ & 748 & 9,519 & 5,998 & 297 & 27 & 9 & 372 & 51 & 2 \\
\hline & 2016 & $1,382,705$ & 698 & 2,904 & 3,310 & 27 & 18 & 51 & 1,073 & 35 & 1 \\
\hline \multirow[t]{5}{*}{ Winter } & 2012 & 170,323 & 615 & 7,168 & 6 & 33 & 2 & 0 & 3 & 1 & 0 \\
\hline & 2013 & 164,201 & 536 & 4,866 & 23 & 99 & 0 & 0 & 0 & 0 & 0 \\
\hline & 2014 & 174,594 & 520 & 5,787 & 17 & 80 & 0 & 0 & 19 & 0 & 0 \\
\hline & 2015 & 154,125 & 513 & 2,059 & 49 & 5 & 0 & 0 & 33 & 0 & 0 \\
\hline & 2016 & 142,624 & 610 & 4,433 & 0 & 3 & 0 & 0 & 5 & 0 & 0 \\
\hline
\end{tabular}

${ }^{a}$ No observations of spindle tuber or bacterial ring rot were recorded in either summer or winter inspections from 2012 to 2016. 
0.0001). Based on the model, we observed that seed generation of some varieties presents a strong, but inconsistent pattern on sensitivity to mosaic or blackleg (Supplementary Table S5 and S6). Russet Norkotah 278 showed the expected pattern: newer generations had less mosaic than older generations and gradually decreased positive coefficients were observed in summer inspections. In contrast, older generations of varieties including Anuschka, Chipeta, and Russet Nugget were predicted to be less sensitive to mosaic with negative coefficients when compared with baselines (i.e., newest seed generation) $\left(\beta_{\text {AnuschkaxGeneration 3 }}=-2.3454, P=0.0493 ; \beta_{\text {AnuschkaxGeneration } 3}=\right.$ $-2.3667, P=0.0004 ; \beta_{\text {ChipetaxGeneration } 3}=-1.7958, P=0.0058$; $\beta_{\text {ChipetaxGeneration 3 }}=-1.8078, P<0.0001 ; \beta_{\text {Russet Nugget } x \text { Generation } 2}=$ $\left.-1.7197, P<0.0001 ; \beta_{\text {Russet Nugget } \times \text { Generation } 3}=-1.4742, P=0.0293\right)$. Effects of seed generations of Anuschka, Canela Russet, Chipeta, Mesa Russet, Russet Nugget, or Rio Grande Russet on mosaic incidences were consistent (high or low) in both summer and winter inspections.

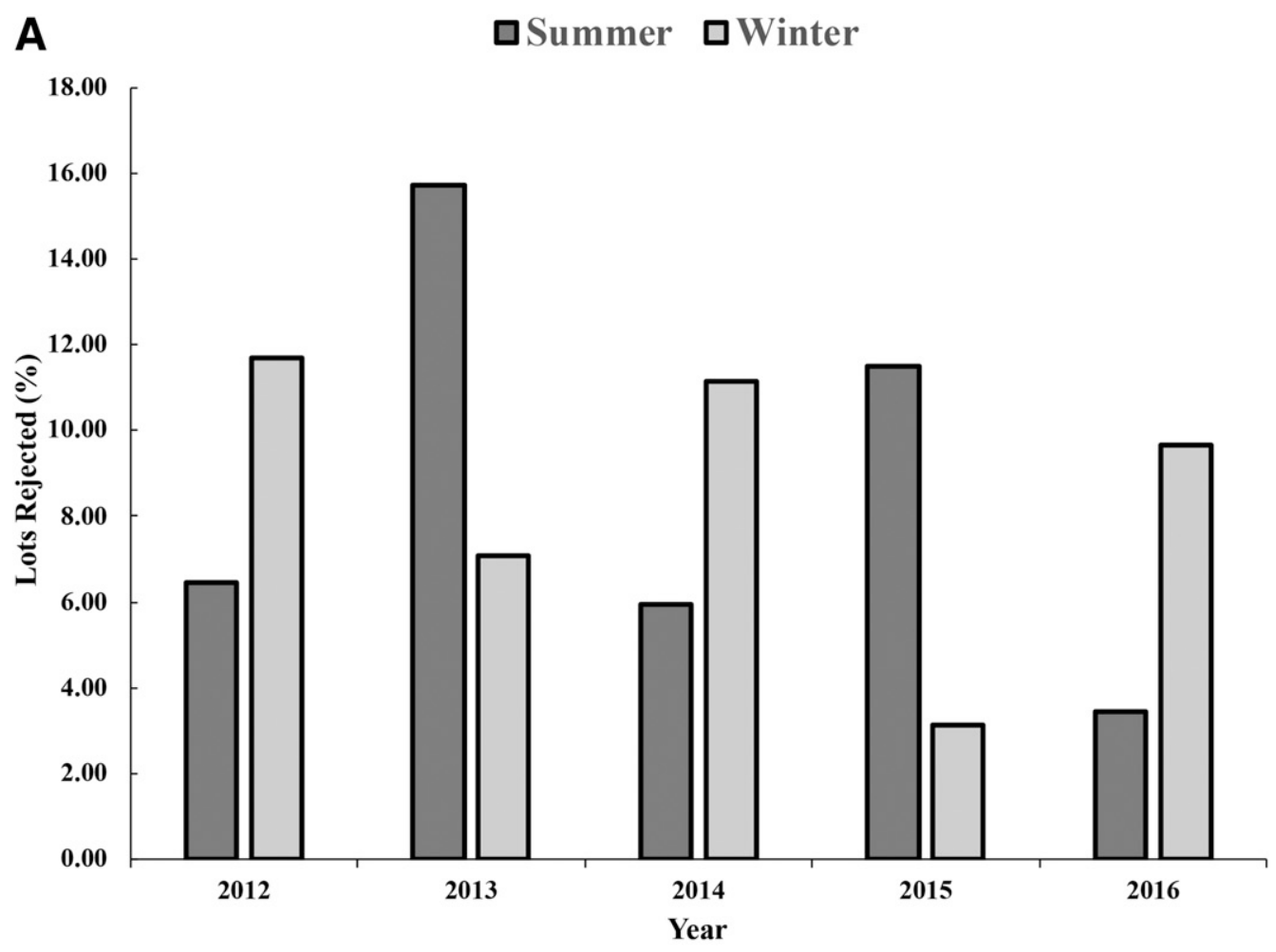

B

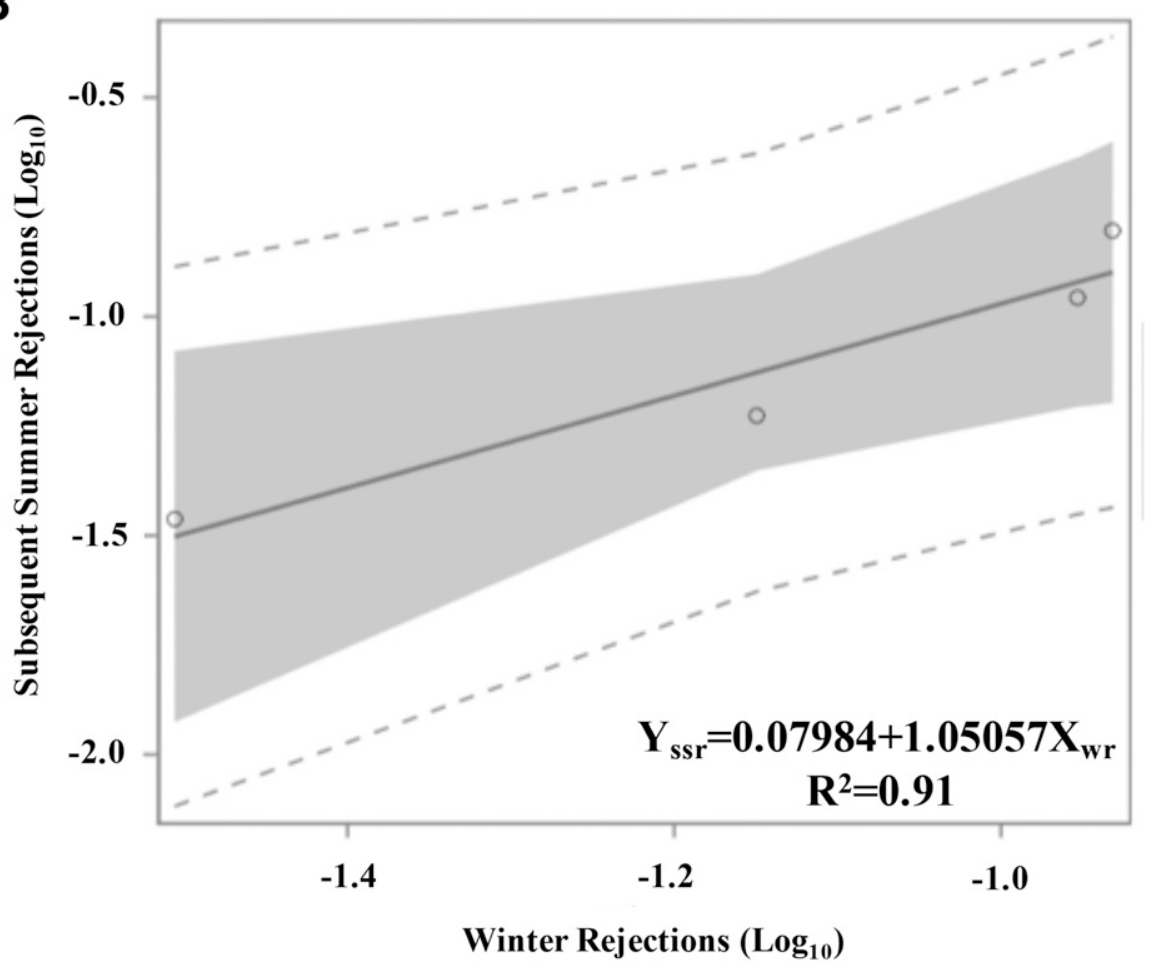

Fig. 1. A, Proportion of seed potato lots rejected in the summer and winter inspections from 2012 to 2016 in the SLV region. B, Relationship between lot rejection measured in the summer inspections and lot rejection measured in the preceding winter inspections. $Y_{\text {ssr }}$ : mean rejection for the subsequent summer inspection; $X_{w r}$ : mean rejection for the winter inspection; $\mathrm{R}^{2}$ : indicated the predicted regression model accounted for $91 \%$ of the variance. 
Similarly, seed generation 3 of Anuschka appeared to have a higher blackleg incidence than the seed generation 4 , which is unexpected if risk increases over time, although the coefficient of Anuschka generation 3 was not significant $\left(\beta_{\text {AnuschkaxGeneration } 3}=0.8994, P=0.11\right)$. However, blackleg incidence of recent generations of LaRatte, Russet Norkotah 112, Russet Norkotah 296, and Russet Norkotah 3 were greater than older seed generations. Other examined varieties did not show a clear pattern of the generation effect on mosaic and blackleg incidences over the same period.

Relationship between aphid abundance and mosaic and leaf roll incidence. Captures of aphids, including M. persicae, A. pisum, and $M$. euphorbiae in the SLV region allowed us to determine if their relative abundance can be correlated with variabilities in the incidence of mosaic and leafroll symptoms that occurred in seed potato lots during the summer and winter inspections. In general, greater numbers of $M$. persicae were captured from July to August in the region than A. pisum or M. euphorbiae (Fig. 3). Across inspection years, captures of $M$. persicae in 2015 were higher compared with captures in other years, while the number of $A$. pisum or M. euphorbiae captured in 2012 was higher than in other years. PLRV is persistently transmitted by a few aphid species (i.e., $M$. persicae, $A$. pisum, and $M$. euphorbiae); however, none of the captured aphids showed positive correlations to disease incidence of PLRV (Table 4). Instead, a negative relationship was observed between PLRV incidence and captures of $A$. pisum or M. euphorbiae, although it was not significant (Table 4; $R=-0.23, P=0.7057, \alpha=0.1$ ). PVY can be transmitted by numerous potato-colonizing and non-potato-colonizing aphid species (i.e., M. persicae, M. euphorbiae) during summer in the field. There was no significant correlation between PVY and M. persicae or between PVY and the other two vectors in summer, but a strong negative

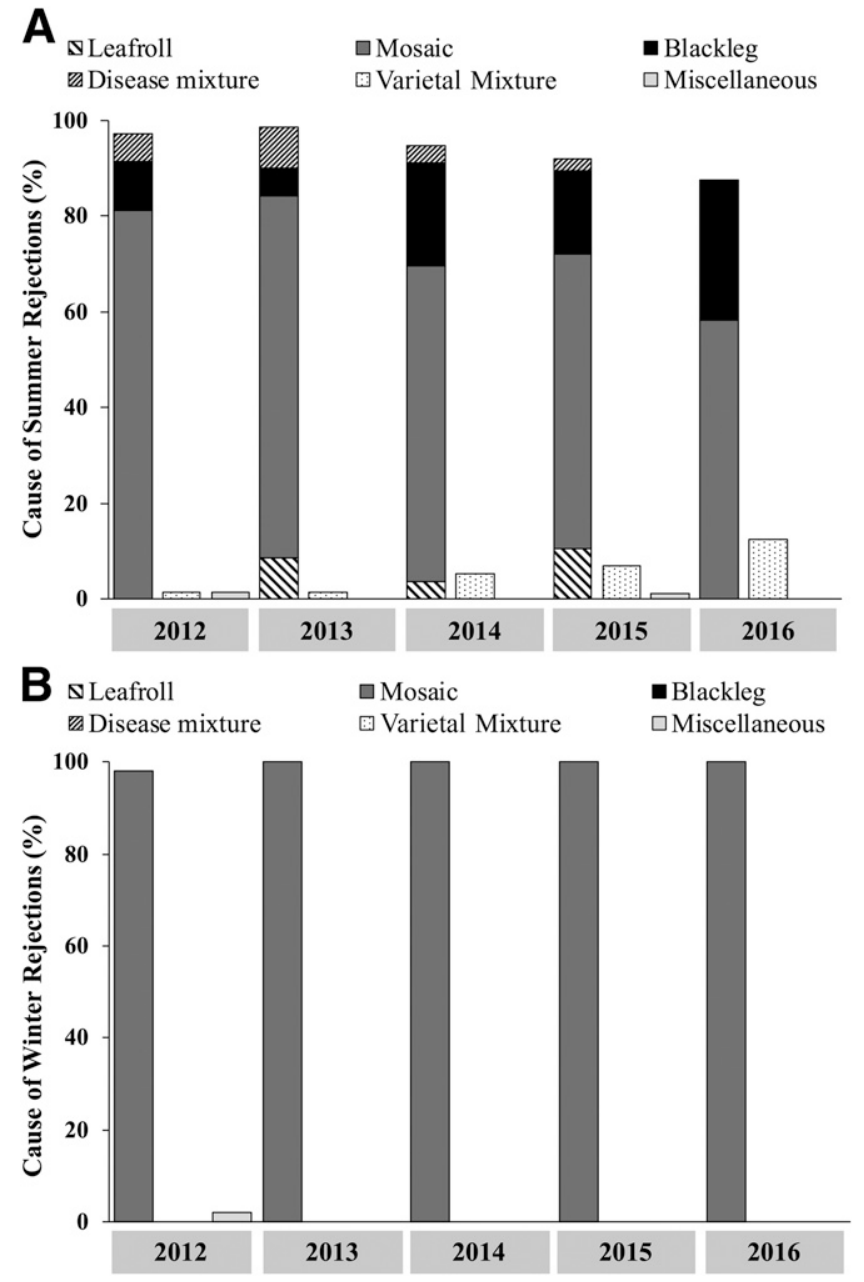

Fig. 2. Cause of rejections shown as a proportion of total rejections. A, Cause of rejections in the summer inspections. B, Cause of rejections in the winter inspections. correlation $(R=-0.88, P=0.0514, \alpha=0.1)$ between PVY incidences in winter inspections and $M$. persicae was observed (Table 4). We did not identify any significant correlations between cumulative aphid captures and disease incidences in summer or winter inspections (Table 4).

\section{Discussion}

We analyzed potato disease prevalence and different factors influencing disease incidences from 2012 to 2016 in the SLV region of

Table 2. Wald statistics for type 3 analysis for the logistic regression models relating to incidences of potato diseases, disorders, and varietal mixtures in the summer and winter inspections (2012-2016) ${ }^{\mathrm{a}}$

\begin{tabular}{|c|c|c|c|c|c|}
\hline & Disease & Source & df & Wald $\chi^{2}$ & $P>\chi^{2 b}$ \\
\hline \multirow[t]{21}{*}{ Summer } & Mosaic & Year & 4 & 292.53 & $<0.0001 * *$ \\
\hline & & Variety & 311 & $8,246.94$ & $<0.0001 * *$ \\
\hline & & Year×Variety & 556 & $14,636.8$ & $<0.0001 * *$ \\
\hline & Blackleg & Year & 4 & 167.75 & $<0.0001 * *$ \\
\hline & & Variety & 311 & $3.046 \mathrm{e} 7$ & $<0.0001 * *$ \\
\hline & & Year×Variety & 556 & $2.62 \mathrm{e} 11$ & $<0.0001 * *$ \\
\hline & Leafroll & Year & 4 & $1,493.37$ & $<0.0001 * *$ \\
\hline & & Variety & 311 & $3.315 \mathrm{e} 8$ & $<0.0001 * *$ \\
\hline & & Year×Variety & 556 & $7.07 \mathrm{e} 10$ & $<0.0001 * *$ \\
\hline & Calico & Year & 4 & 10.78 & $0.0291 *$ \\
\hline & & Variety & 311 & 120.5 & 0.9999 \\
\hline & & Year×Variety & 556 & 35.42 & 1.0000 \\
\hline & Haywire & Year & 4 & 2.65 & 0.6175 \\
\hline & & Variety & 311 & 18. 28 & 0.8763 \\
\hline & & Year×Variety & 556 & 67.02 & 1.0000 \\
\hline & $\begin{array}{l}\text { Varietal } \\
\text { mixture }\end{array}$ & Year & 4 & 86.41 & $<0.0001 * *$ \\
\hline & & Variety & 311 & $1.7 \mathrm{e} 11$ & $<0.0001 * *$ \\
\hline & & Year×Variety & 556 & 7.1e6 & $<0.0001 * *$ \\
\hline & Variant & Year & 4 & 0.4 & 1.0000 \\
\hline & & Variety & 311 & 87.55 & 1.0000 \\
\hline & & Year×Variety & 556 & 125.61 & 1.0000 \\
\hline \multirow[t]{12}{*}{ Winter } & Mosaic & Year & 4 & 133.36 & $<0.0001 * *$ \\
\hline & & Variety & 174 & $4,275.26$ & $<0.0001 * *$ \\
\hline & & Year×Variety & 242 & $5,433.82$ & $<0.0001 * *$ \\
\hline & Blackleg & Year & 4 & 0.59 & 0.7658 \\
\hline & & Variety & 174 & 25.82 & 0.4658 \\
\hline & & Year×Variety & 242 & $5,982.91$ & $<0.0001 * *$ \\
\hline & Leafroll & Year & 4 & 4.28 & 0.5176 \\
\hline & & Variety & 174 & 591.34 & $<0.0001 * *$ \\
\hline & & Year×Variety & 242 & $3.52 \mathrm{e} 8$ & $<0.0001 * *$ \\
\hline & Varietal & Year & 4 & 5.36 & 0.4458 \\
\hline & & Variety & 174 & $5.9 \mathrm{e} 10$ & $<0.0001 * *$ \\
\hline & & Year×Variety & 242 & $3.8 \mathrm{e} 5$ & $<0.0001 * *$ \\
\hline
\end{tabular}

a Giant hill in the summer inspections, varietal mixture, variant, calico, haywire, and giant hill in the winter inspections were not shown due to their extremely low incidences.

b $* P<0.05 ; * * P<0.01$.

Table 3. Wald statistics for type 3 analysis for the logistic regression model testing effects of variety, generation, and their interactions on mosaic and blackleg (2012-2016)

\begin{tabular}{|c|c|c|c|c|c|}
\hline & Disease & Source & df & Wald $\chi^{2}$ & $P>\chi^{2 a}$ \\
\hline \multirow[t]{6}{*}{ Summer } & Mosaic & Variety & 15 & $1,428.23$ & $<0.0001 * *$ \\
\hline & & Generation & 6 & $2,669.46$ & $<0.0001 * *$ \\
\hline & & Variety $\times$ Generation & 43 & $4,523.72$ & $<0.0001 * *$ \\
\hline & Blackleg & Variety & 15 & 380.62 & $<0.0001 * *$ \\
\hline & & Generation & 4 & 42.58 & $<0.0001 * *$ \\
\hline & & Variety $\times$ Generation & 27 & $1,268.23$ & $<0.0001 * *$ \\
\hline \multirow[t]{3}{*}{ Winter } & Mosaic & Variety & 15 & 667.98 & $<0.0001 * *$ \\
\hline & & Generation & 5 & 112.80 & $<0.0001 * *$ \\
\hline & & Variety $\times$ Generation & 47 & 845.51 & $<0.0001 * *$ \\
\hline
\end{tabular}

a $* * P<0.05$. 
Colorado. During this period, we found that mosaic and blackleg were both major and persistent problems and resulted in a high proportion of seed lot rejections, whereas other problems recorded by the certification program had lower incidence when compared with mosaic or blackleg. The number of plants with mosaic symptoms has decreased since 2015 , possibly attributed to efforts made in tightening seed certification regulations, roguing diseased plants, planting symptom-free seed tubers, early vine killing, or spraying mineral oil prior to the arrival of aphids (Boiteau et al. 2009; Gray et al. 2010; Wale et al. 2008). However, the nonpersistently transmitted manner of PVY by numerous potato-colonizing or non-potato-colonizing aphid species, ineffectiveness of insecticide applications (i.e., neonicotinoid) to control vectors, and the lack of PVY-resistant varieties result in this pathogen still being the most common cause of downgrading or rejection of seed potato acreage (Boiteau and Singh 1999; Gray et al. 2010).

In Wisconsin, which produces approximately the same amount of seed potatoes as Colorado, the majority (43.6\%) of rejections of seed potato acreage reported in the summer and winter inspections from 2002 to 2010 was caused by PVY, which was similar to our findings, even though PVY tolerance is slightly higher in Colorado for both summer and winter inspections. However, varietal mixture was responsible for more than $21 \%$ of rejections over that same time period in Wisconsin (Frost et al. 2013); tolerances for varietal mixtures are similar between the two states. Rejections due to pesticide application errors were also common in Wisconsin. In contrast, in Colorado, less than $6 \%$ of seed lots were rejected due to varietal mixture, and pesticide application errors were not a cause of rejection during these years. Differences in pesticide application error incidence may be due to the greater use of pesticides in Wisconsin potato production than in Colorado due to climate differences that favor diseases, weeds, and insect pests in Wisconsin (estimated annual agricultural pesticide use map is available online from the U. S. Geological Survey Home Page; https://water.usgs.gov/nawqa/ $\mathrm{pnsp} / \mathrm{usage} / \mathrm{maps} /$ ) or because more residual herbicides left in equipment from other crops in Wisconsin.

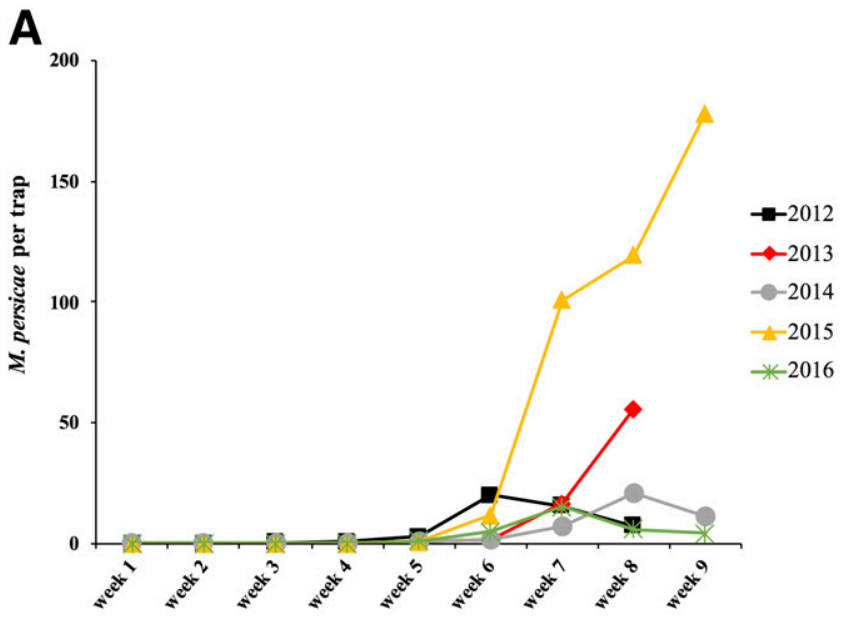

In Wisconsin, only $7 \%$ of downgrades or rejections of seed potato acreage were caused by blackleg (Frost et al. 2013), but blackleg led to approximately $17 \%$ of summer rejections in Colorado. Blackleg is not specifically mentioned in Wisconsin certification regulations, so rejections only occur when the inspector believes that this disease is at a high enough incidence to cause significant losses. In contrast, the Colorado certification rules allow a $4 \%$ tolerance for this disease. Blackleg was rarely observed in postharvest inspections, likely because the plants are only inspected a few weeks after emergence, prior to when blackleg typically develops, or because soil temperature where postharvest grow-out inspection test occurs is different. Field tolerance of blackleg disease was excluded from the certification disease list of several seed potato certification rules and regulations (Shepard and Claflin 1975). Recently, the outbreak of Dickeya spp. has caused significant losses in some potato producing areas in the U.S. (Czajkowski et al. 2011; Jiang et al. 2016). With increasing incidences of blackleg disease, including blackleg on the certification disease list and providing management strategies to prevent its introduction and spread seems to be crucial and timely. Blackleg resistance is likely multigenic and there are few field data available comparing tolerance/ resistance of commercial potato varieties to blackleg.

Certain varietal responses to mosaic, blackleg, or leafroll were consistent among years. For example, varieties such as Russet Norkotah, Red Gold, CalWhite, and Russet Nugget had mosaic symptoms more often than AC99375-1RU, Agata, Satina, Ciklamen, Laura, and Teton Russet. The varieties Agata, Satina, Ciklamen, Laura, and Gala are listed as highly or moderately PVY-resistant in the Canadian and European potato databases, although the source of the resistance of some varieties is unclear. Ciklamen was reported to carry PVY resistant gene $R y_{\text {sto }}$ in previous studies (Fulladolsa et al. 2015; Heldák et al. 2007). Rio Grande Russet was previously reported to carry an $N$-gene (Rowley et al. 2015), which provides resistance against PVY NA-N and these data suggest that this $N$-gene is not effective against PVY strains in Colorado. In contrast, Teton Russet, Lamoka, and Satina were previously reported to be PVY-sensitive and our data suggest that host preference differences of PVY vectors,

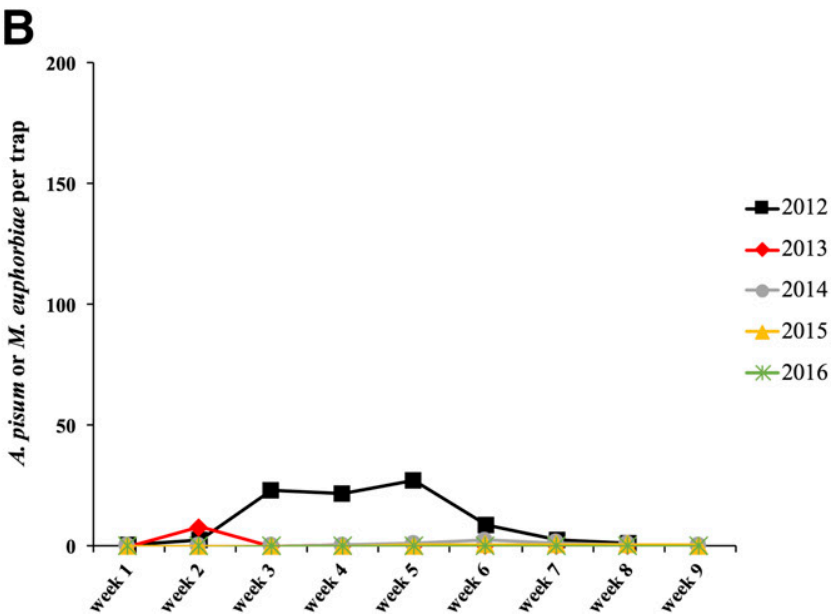

Fig. 3. Weekly region-wide captures of virus vectors from July to August in the SLV. A, The trend of abundance of M. persicae in 2012-2016. B, The trend of abundance of A. pisum and/or M. euphorbiae in 2012-2016.

Table 4. Correlation analysis of disease incidence and the abundance of aphid vectors in the SLV region from 2012 to 2016

\begin{tabular}{|c|c|c|c|c|c|c|c|c|c|c|c|}
\hline & \multirow[b]{2}{*}{ Disease } & \multicolumn{2}{|c|}{ M. persicae } & \multicolumn{2}{|c|}{$\begin{array}{l}\text { A. pisum and/or } M \text {. } \\
\text { euphorbiae }\end{array}$} & \multicolumn{2}{|c|}{ D. noxia } & \multicolumn{2}{|c|}{ Miscellaneous aphid } & \multicolumn{2}{|c|}{ Cumulative aphids } \\
\hline & & $R^{\mathrm{a}}$ & $P$-value ${ }^{\mathrm{b}}$ & $R$ & $P$-value & $R$ & $P$-value & $R$ & $P$-value & $R$ & $P$-value \\
\hline \multirow[t]{2}{*}{ Summer } & Mosaic & 0.36 & 0.5566 & 0.13 & 0.8386 & 1.00 & $\ldots$ & -0.5529 & 0.3337 & 0.19 & 0.7628 \\
\hline & Leafroll & 0.36 & 0.5536 & -0.34 & 0.5702 & 1.00 & $\ldots$ & -0.6230 & 0.1133 & -0.01 & 0.9877 \\
\hline \multirow[t]{2}{*}{ Winter } & Mosaic & -0.88 & $0.0514 *$ & 0.49 & 0.4064 & 1.00 & $\ldots$ & 0.43 & 0.4717 & -0.62 & 0.2682 \\
\hline & Leafroll & -0.24 & 0.6977 & 0.19 & 0.7545 & 1.00 & $\ldots$ & -0.46 & 0.4413 & -0.40 & 0.4997 \\
\hline
\end{tabular}

\footnotetext{
${ }^{\mathrm{a}} R$ : Pearson correlation coefficient.
}

b $* P<0.1 ; \alpha=0.1$. 
clean seed sources, plant maturity, or an unrecognized $N$-gene may impact disease incidence in these varieties (Fulladolsa et al. 2015; Hamm et al. 2010; Novy et al. 2014). Seed growers and certification agencies would benefit from easily accessible genetic information about disease resistance to more quickly identify unexpected disease phenotypes that indicate that a new virus species or strains has emerged in a seed supply or when other conditions change that impact seed supply health.

Visual inspection is mainly used for seed potato certification in Colorado because the cost of laboratory testing remains prohibitive. PVY and PLRV cause mild symptoms in some varieties, but our data suggest that visual inspection still provides useful data. Seed certification agencies maintain a list of varieties known to show mild symptoms with PVY and the majority of these varieties were identified as susceptible in our analysis, demonstrating that inspectors were able to identify infected plants in these varieties. A large portion of varieties that showed a year-variety interaction were varieties that develop mild PVY symptoms, suggesting that this year-variety interaction may be due to varieties that develop mild symptoms having inconsistent symptom development that is either missed by inspectors or affected by crop year.

According to our analysis, growers could adapt potato crop production systems to minimize disease incidences if potato variety resistance/tolerance was taken into account as an important disease management practice. Variety selection with high pathogen resistance/tolerance in addition to high yields is important in order to effectively control these diseases. Notably, several varieties displayed similar susceptibility to both mosaic and blackleg or some of the predicted PVY-tolerant varieties were highly or moderately sensitive to blackleg. Comparing defense responses of potato plants to mosaic and blackleg at the transcriptome level may be conducive to reveal the molecular basis of sensitivity and/or resistance of the hosts to disease infections (Thangavel et al. 2014), and may further provide insights for potato genome editing (Bradeen et al. 2009; Roman et al. 2017).

The limited generation seed system used in potato is based on the concept that the risk of disease increases each year that a seed lot is multiplied in the field. We found that seed generation effects varied among potato varieties and that later generations did not always have higher disease incidence, which is consistent with the findings of Boyd et al. (2018), where plants grown from generation 3 tubers of Russet Burbank developed PVY at a lower incidence than plants grown from tissue culture plantlets (nuclear generation). We interpret this as demonstrating that the current system (i.e., certification practices such as roguing diseased plants, planting symptom-free seed tubers, etc.) reduces risk sufficiently so that seed from later generations that is within certification tolerances is not more risky to plant than seed from earlier generations.

PLRV symptoms were reduced to nearly undetectable levels in most seed potato production systems except in 2013 (Table 1). In two of these five years, no leafroll symptoms resulted in rejection of seed potato lots (Fig. 2). Similar results were seen in Wisconsin, where the total PLRV incidence was less than 10 plants per year in summer and winter inspections from 2006-2011 (Frost et al. 2013). These results indicated that a clean seed source was provided to growers and plant protection strategies such as widespread use of systemic neonicotinoid insecticides, which target the potatocolonizing aphid species (green peach aphid M. persicae and potato aphid $M$. euphorbiae) have greatly controlled the spread of this persistently transmitted virus (Boiteau and Singh 1999; Marsh et al. 2000; Ragsdale et al. 2001). PLRV appears to mainly occur on organic farms, leading to $4.5 \%$ of rejected seed lots from 2013 to 2015 (Fig. 2). Organic farms only have access to non-systemic and quickly degraded insecticides rather than systemic insecticides, which is the likely reason for higher PLRV levels on these farms. Other plant protection practices, such as applications of mineral oil, straw mulching, or border crops may reduce PLRV infections on organic farms (Boiteau et al. 2009; Dupuis et al. 2010; Fereres 2000; Heimbach et al. 2004; Kirchner et al. 2014; Martín-López et al. 2006; Saucke and Döring 2004).
M. persicae, generally viewed as the most efficient vector of PVY, did not correlate with mosaic incidence, nor did A. pisum and/or $M$. euphorbiae. For example, M. persicae abundance was higher in 2015 than in other years and its captures were uniformly spread across the valley, but PVY levels were low in both the current season and postharvest data for this year (http://www.agro.com/aphidnumbers.html). This contrasts with the strong positive correlation between lateseason PVY prevalence and cumulative aphid abundance in Idaho (Mondal et al. 2016; Steinger et al. 2015). The lack of correlation suggests that either the capture method used was inappropriate for studying the impact of aphid abundance on PVY incidence or that PVY prevalence might be more strongly affected by seed source, farm management practices (e.g., vine kill timing), variety susceptibility, or climate (Frost et al. 2013). Overall aphid abundance can impact both aphid movement and vector efficiency and these complex interactions may be responsible for the negative correlation observed between postharvest PVY incidence and $M$. persicae abundance (Claflin et al. 2017; Kotzampigikis et al. 2009).

In conclusion, we found that PVY and blackleg are the two most prevalent diseases in seed potatoes in Colorado and that these diseases occur in similar levels as in Wisconsin, which is the only other state where similar analyses have been completed. The seed potato certification dataset also allowed identification of tolerant and sensitive potato varieties for these two diseases, but unfortunately, none of the over 304 varieties examined were tolerant to both PVY and blackleg. We were unable to correlate aphid abundance with PVY and PLRV incidence, suggesting that the trapping network currently in place could be improved to better represent aphid activity in potato fields. The value of this dataset in disease epidemiology and identification of tolerant varieties suggests that if seed potato inspections were expanded to include data on visual inspections for additional diseases, even if the diseases are not included as reasons for seed potato rejections, that the data collected could inform farmers and epidemiologists on the impact of variety choice and management practices and help them reduce the risk of loss to disease.

\section{Acknowledgments}

We thank the Colorado Seed Potato Certification Agency and Colorado Potato Growers for their assistance with this work. The authors also thank Agro Engineering for aphid count data collected in SLV region.

\section{Literature Cited}

Ali, H. F., Ahmad, M., Junaid, M., Bibi, A., Ali, A., Sharif, M. U. H. A. M. M. A. D., Ali, B., Nawab, K. H. A. L. I. D., and Sadozai, A. 2012. Inoculum sources, disease incidence and severity of bacterial blackleg and soft rot of potato. Pak. J. Bot. 44: 825-830.

Bagnall, R. H. 1988. Epidemics of potato leafroll in North America and Europe linked to drought and sun spot cycles. Can. J. Microbiol. Plant Pathol. 10:193-202.

Bagnall, R. H. 1992. Epidemiology of potato virus $Y$ in New Brunswick, Canada; a biennial rhythm and a 9-plus year cycle. Can. J. Plant Pathol. 14:137-146.

Bohl, W. H., Nolte, P., and Thornton, M. K. 1992. Potato seed management: Seed certification and selection.University of Idaho, Cooperative Extension Service, Agricultural Experiment Station, Moscow, ID.

Boiteau, G., Singh, M., and Lavoie, J. 2009. Crop border and mineral oil sprays used in combination as physical control methods of the aphid-transmitted potato virus $Y$ in potato. Pest Manag. Sci. 65:255-259.

Boiteau, G., and Singh, R. P. 1999. Field assessment of imidacloprid to reduce the spread of PVY ${ }^{\mathrm{O}}$ and PLRV in Potato. Am. J. Potato Res. 76:31-36.

Boyd, E., Carpenter, E., Ross, B. T., Zidack, N., and Flenniken, M. L. 2018. Potato cultivar and seed type affect the development of systemic potato virus Y (PVY N-Wi) Infection. Am. J. Potato Res. 95:183-190.

Bradeen, J. M., Iorizzo, M., Mollov, D. S., Raasch, J., Kramer, L. C., Millett, B. P., Austin-Phillips, S., Jiang, J., and Carputo, D. 2009. Higher copy numbers of the potato RB transgene correspond to enhanced transcript and late blight resistance levels. Mol. Plant-Microb. Interact. 22:437-446.

Claflin, S. B., Power, A. G., and Thaler, J. S. 2017. Aphid density and community composition differentially affect apterous aphid movement and plant virus transmission. Ecol. Entomol. 42:245-254.

Czajkowski, R., Perombelon, M. C., van Veen, J. A., and van der Wolf, J. M. 2011 Control of blackleg and tuber soft rot of potato caused by Pectobacterium and Dickeya species: a review. Plant Pathol. 60:999-1013.

De Boer, S. H. 2004. Blackleg of potato. The Plant Health Instructor. doi:10.1094/ PHI-I-2004-0712-01

Dupuis, B., Schwaerzel, R., Goy, G., Tallant, M., and Derron, J. 2010. Stepwise development of an efficient method to control Potato virus Y spread in seed 
potato fields. Page 22 in: Proceedings of the European Association for Potato Research, virology section, meeting, 2010. C. Spetz and D. R. Blystad, eds. Bioforsk Fokus, Hamar, Norway.

Fereres, A. 2000. Barrier crops as a cultural control measure of non-persistently transmitted aphid-borne viruses. Virus Res. 71:221-231.

Frost, K. E., Groves, R. L., and Charkowski, A. O. 2013. Integrated control of potato pathogens through seed potato certification and provision of clean seed potatoes. Plant Dis. 97:1268-1280.

Fulladolsa, A. C., Navarro, F. M., Kota, R., Severson, K., Palta, J. P., and Charkowski, A. O. 2015. Application of marker assisted selection for Potato virus $Y$ resistance in the University of Wisconsin Potato Breeding Program. Am. J. Potato Res. 92:444-450.

Gray, S. M., De Boer, S. H., Lorenzen, J. H., Karasev, A. V., Whitworth, J., Nolte, P., Singh, R., Bouche, A., and Xu, H. 2010. Potato virus $Y$, an evolving concern for potato crops in the United States and Canada. Plant Dis. 94:1384-1397.

Hamm, P. B., Hane, D. C., Pavek, M. J., Leroux, L. D., Gieck, S. L., and David, N. L. 2010. Potato cultivars differ in current season Potato virus Y (PVY) infection. Am. J. Potato Res. 87:19-26.

Heimbach, U., Eggers, C., and Thieme, T. 2004. Effect of mulch on aphid populations and virus transmissions in some arable crops. Pages 307-312 in: Proceedings of the Aphids in a New Millennium, 2004. J. C. Simon, C. A. Dedryver, C. Rispe, and M. Hulle, eds. INRA Editions, Paris.

Heldák, J., Bežo, M., Stefúnová, V., and Galliková, A. 2007. Selection of DNA markers for detection of extreme resistance to Potato virus $Y$ in tetraploid potato (Solanum tuberosum L.) $\mathrm{F}_{1}$ progenies. Czech J. Genet. Plant Breed. 43:125-134.

Jiang, H. H., Hao, J. J., Johnson, S. B., Brueggeman, R. S., and Secor, G. 2016. First Report of Dickeya dianthicola Causing Blackleg and Bacterial Soft Rot on Potato in Maine. Plant Dis. 100:2320.

Kirchner, S. M., Hiltunen, L. H., Santala, J., Döring, T. F., Ketola, J., Kankaala, A., Virtanen, E., and Valkonen, J. P. T. 2014. Comparison of straw mulch, insecticides, mineral oil, and birch extract for control of transmission of Potato virus $Y$ in seed potato crops. Potato Res. 57:59-75.

Kotzampigikis, A., Hristova, D., and Tasheva-Terzieva, E. 2009. Virus-vector relationship between Potato virus Y-PVY and Myzus persicae Sulzer. Bulg. J. Agric. Sci. 15:557-565.

Ling, K. S., Li, R., Panthee, D. R., and Gardner, R. G. 2013. First report of Potato spindle tuber viroid naturally infecting greenhouse tomatoes in North Carolina. Plant Dis. 97:148.

Ling, K. S., and Sfetcu, D. 2010. First report of natural infection of greenhouse tomatoes by Potato spindle tuber viroid in the United States. Plant Dis. 94:1376.

Loebenstein, G., and Gaba, V. 2012. Viruses of potato. Pages 210-246 in: Viruses and Virus Diseases of Vegetables in the Mediterranean Basin. G. Loebenstein and H. Lecoq, eds. Academic Press, San Diego.

Magnuson, J. J. 1990. Long-term ecological research and the invisible present. BioSci. 40:495-501.

Marsh, T. L., Huffaker, R. G., and Long, G. E. 2000. Optimal control of vectorvirus-plant interactions: the case of potato leafroll virus net necrosis. Am. J. Agric. Econ. 82:556-569.

Martín-López, B., Varela, I., Marnotes, S., and Cabaleiro, C. 2006. Use of oils combined with low doses of insecticide for the control of Myzus persicae and PVY epidemics. Pest Manag. Sci. 62:372-378.
Mondal, S., Wenninger, E. J., Hutchinson, P. J., Weibe, M. A., Eigenbrode, S. D. and Bosque-Pérez, N. A. 2016. Contribution of noncolonizing aphids to Potato Virus $Y$ prevalence in potato in Idaho. Environ. Entomol. 45:1445-1462.

Novy, R. G., Whitworth, J. L., Stark, J. C., Charlton, B. A., Yilma, S., Knowles, N. R., Pavek, M. J., Spear, R. R., Brandt, T. L., Olsen, N., Thornton, M., and Brown, C. R. 2014. Teton russet: an early-maturing, dual-purpose potato cultivar having higher protein and vitamin $\mathrm{C}$ content, low asparagine, and resistances to common scab and fusarium dry rot. Am. J. Potato Res. 91:380-393.

Ragsdale, D. W., Radcliffe, E. B., and DiFonzo, C. D. 2001. Epidemiology and field control of PVY and PLRV. Pages 237-270 in: Virus and virus-like diseases of potatoes and production of seed-potatoes. G. Loebenstein, P. H Berger, A. A. Brunt, and R. H. Lawson, eds. Springer, Dordrecht, The Netherlands.

Rahman, M. S., Akanda, A. M., Mian, I. H., Bhuian, M. K. A., and Karim, M. R. 2010. Growth and yield performance of different generations of seed potato as affected by PVY and PLRV. Bangladesh J. Agric. Res. 35:37-50.

Roman, M. L., Izarra, M., Lindqvist-Kreuze, H., Rivera, C., Gamboa, S., Tovar, J. C., Forbes, G. A., Kreuze, J. F., and Ghislain, M. 2017. R/Avr gene expression study of Rpi-vntl. 1 transgenic potato resistant to the Phytophthora infestans clonal lineage EC-1. Plant Cell Tissue Organ Cult. 131:259-268.

Rowley, J. S., Gray, S. M., and Karasev, A. V. 2015. Screening potato cultivars for new sources of resistance to Potato virus Y. Am. J. Potato Res. 92:38-48.

Sagarin, R., and Pauchard, A. 2010. Observational approaches in ecology open new ground in a changing world. Front. Ecol. Environ. 8:379-386.

Saucke, H., and Döring, T. F. 2004. Potato virus $Y$ reduction by straw mulch in organic potatoes. Ann. Appl. Biol. 144:347-355.

Scholthof, K. B. G., Adkins, S., Czosnek, H., Palukaitis, P., Jacquot, E., Hohn, T., Hohn, B., Saunders, K., Candresse, T., Ahlquist, P., Hemenway, C., and Foster, G. D. 2011. Top 10 plant viruses in molecular plant pathology. Mol. Plant Pathol. 12:938-954.

Shepard, J. F., and Claflin, L. E. 1975. Critical analyses of the principles of seed potato certification. Annu. Rev. Phytopathol. 13:271-293.

Singh, R. P. 2014. The discovery and eradication of Potato spindle tuber viroid in Canada. Virusdisease 25:415-424.

Steinger, T., Goy, G., Gilliand, H., Hebeisen, T., and Derron, J. 2015. Forecasting virus disease in seed potatoes using flight activity data of aphid vectors. Ann. Appl. Biol. 166:410-419.

Sun, M., Siemsen, S., Campbell, W., Guzman, P., Davidson, R., Whitworth, J. L., Bourgoin, T., Axford, J., Schrage, W., Leever, G., and Westra, A. 2004. Survey of Potato spindle tuber viroid in seed potato growing areas of the United States. Am. J. Potato Res. 81:227-231.

Taliansky, M., Mayo, M. A., and Barker, H. 2003. Potato leafroll virus: A classic pathogen shows some new tricks. Mol. Plant Pathol. 4:81-89.

Thangavel, T., Steven Tegg, R., and Wilson, C. R. 2014. Resistance to multiple tuber diseases expressed in somaclonal variants of the potato cultivar Russet Burbank. Sci. World J. 2014:417697.

Wale, S., Platt, B., and Cattlin, N. D. 2008. Diseases, pests and disorders of potatoes: a colour handbook. CRC Press, Boca Raton, FL.

Whitworth, J., and Davidson, R. D. 2008. Quality seed: Seed improvement, cultivar and seed lot selection, and certification. Pages 31-41 in: Potato Health Management. D. A. Johnson, ed. American Phytopathological Society, St. Paul, MN 